\title{
Kajian komparatif lembaga penolakan waris dalam perspektif hukum waris adat dan Islam
}

\author{
Oemar Moechtar ${ }^{1}$, Baren Valentino ${ }^{2}$, Denita Cahyanti Wahono ${ }^{3}$
}

${ }^{1}$ Oemar Moechtar; Fakultas Hukum, Universitas Airlangga Jl. Dharmawangsa Dalam Selatan, Surabaya, 60117, Indonesia.

${ }^{2}$ Baren Valentino; Fakultas Hukum, Universitas Airlangga Jl. Dharmawangsa Dalam Selatan, Surabaya, 60117, Indonesia.

${ }^{3}$ Denita Cahyanti Wahono; Fakultas Hukum, Universitas Airlangga Jl. Dharmawangsa Dalam Selatan, Surabaya, 60117, Indonesia

\section{ARTICLEINFO}

\section{Article history:}

Received 2020-07-25

Received in revised form

2020-09-29

Accepted 2020-12-01

\section{Kata kunci:}

Waris; Penolakan Waris; Hukum

Waris Adat; Hukum Waris Islam

Keywords:

Inheritance; Inheritance Rejection; Adat Inheritance Law; Islamic Inheritance Law

DOI: https://doi.org/10.26905/

idjch. v11i3. 4225.

\section{How to cite item:}

Moechtar, O., Valentino, B., \& Wahono, D. (2020). Kajian komparatif lembaga penolakan waris dalam perspektif hukum waris adat dan Islam. Jurnal Cakrawala Hukum, 11(3). 291-301. doi:10.26905/idjch.v11i3.42.

\section{Corresponding Author:}

* Baren Valentino.

E-mail address: inriastama@gmail.com

\section{Abstrak}

Saat ini lembaga penolakan waris hanya dikenal dalam sistem Hukum Waris Perdata Barat, sedangkan di dalam sistem Hukum Waris Adat mupun Islam belum mengenal istilah ini. Secara harafiah, waris merupakan suatu hak yang dimiliki oleh ahli waris, sehingga di dalam waris tersebut ada kehendak bebas baik menerima maupun menolak suatu waris, sehingga secara naluriah tidak ada siapapun yang dapat mengatur seorang individu untuk menerima, memanfaatkan, maupun menolak suatu warisan. Tujuan dari penelitian ini adalah guna menemukan solusi atas kekosongan hukum yang terjadi pada Lembaga Penolakan Waris di dalam Hukum Waris Adat dan Islam sebagaimana dikomparasikan dengan Hukum Waris Perdata Barat, dengan metode penelitian secara perundang-undangan maupun konseptual. Hasil yang didapat adalah Lembaga Penolakan Waris di Indonesia hanya dikenal dalam Hukum Waris Perdata Barat yang diatur di dalam BW, namun belum atau bahkan tidak dikenal di dalam sistem pewarisan di dalam Hukum Waris Adat maupun di dalam Hukum Waris Islam.

\section{Abstract}

Presently, the institution of inheritance rejection is only known in civil inheritance law system, whereas in the Adat nor Islamic inheritance law system is unfamiliar with this term. Inheritance is a right, rights that belongs to the heir, giving the free will either to accept or reject an inheritance bestowen to the heir which no one can instinctively regulate an individual to accept, use, or reject an inheritance. The purpose of this research is to find solution on antinomy that occurs in Inheritance Rejection on Adat and Islamic Inheritance Law as compared to Inheritance Rejection in civil inheritance law which use research methods through statute approach and conceptual approach. Indonesia Inheritance Rejection arise an issue as the heir who 


\section{Jurnal Cakrawala Hukum, Volume 11 No. 3 Desember 2020}

ISSN PRINT 2356-4962 ISSN ONLINE 2598-6538

wants to reject the transfer of property through inheritance is unable to do so because there are no legal instruments that accommodate the Inheritance Rejection. Inheritance Rejection only known in civil inheritance law regulated in BW however it's not yet or even unknown in Adat and Islam Inheritance Law.

\section{Pendahuluan}

Indonesia mengenal adanya keberlakuan 3 rezim hukum waris dalam sistem hukum pewarisan di Indonesia yakni, Hukum Waris Perdata Barat/Kontinental yang diatur di dalam Burgerlijk Wetboek atau KUH-Perdata (BW), Hukum Waris Adat yang tunduk pada nilai-nilai hukum adat di masyarakat, dan Hukum Waris Islam yang bersumber pada Al-Qur'an. Sifat pluralisme yang dimiliki oleh hukum waris di Indonesia dengan dikenalnya 3 rezim hukum waris dalam sistem hukum pewarisan di Indonesia tentunya merupakan suatu hal yang unik sebab memberikan gambaran kental mengenai keberagaman di Indonesia. Keberagaman yang dimaksud tidak hanya terkait dengan kultur serta budaya namun juga keberlakuan nilai-nilai dalam masyarakat yang di antaranya termasuk pula mengenai keberlakuan hukum waris itu sendiri.

Keberlakuan hukum waris yang plural di Indonesia menghadirkan suatu persoalan yang mana keberlakuan 3 rezim hukum waris di Indonesia tersebut menimbulkan suatu interpretasi yang jamak, mengenai rezim hukum waris manakah yang paling tepat untuk diimplementasikan apabila timbul suatu keadaan di mana subyek atau pelaku dalam suatu peristiwa waris ialah orangorang yang tunduk pada beberapa rezim hukum yang berbeda (Haries, 2013). Sebagai contoh adalah pewaris dan si mewaris atau ahli waris yang berbeda agama atau berbeda suku yang memiliki konsekuensi untuk tunduk pada nilai-nilai adat atau masyarakat dari daerah asal.

Perbedaan rezim waris antara pewaris dan ahli waris inilah yang kemudian menjadi perma- salahan selanjutnya adalah bahwa dari ketiga rezim hukum waris ini yang dituangkan ke dalam suatu peraturan perundang-undangan hanyalah Hukum Waris Perdata Barat yakni dituangkan dalam Burgerlijk Wetboek atau KUH-Perdata (BW), sedangkan untuk Hukum Waris Islam merujuk pada Al-Quran dan Hukum Waris Adat merujuk pada nilai-nilai yang berlaku di masyarakat yang sayangnya tidak memiliki bentuk yang tertulis, sehingga yang memiliki daya ikat yang kuat ialah hukum yang dituangkan ke dalam peraturan perundang-undangan sebagaimana Negara ini menganut sistem Civil Law yang mengedepankan hukum tertulis (peraturan perundang-undangan) sebagai sumber hukum primer.

Salah satu problema di dalam sistem hukum waris di Indonesia adalah adanya suatu lembaga penolakan waris. Lembaga penolakan waris sendiri hanya dikenal dalam Hukum Waris Perdata Barat yang diatur di dalam BW, khususnya di dalam Pasal 1057 sampai dengan 1065. Secara implisit, pengaturan mengenai lembaga penolakan warisan memiliki makna bahwa si mewaris atau ahli waris berhak menolak suatu warisan bilamana dengan diterimanya suatu warisan tersebut dapat menimbulkan kerugian bagi si penerima waris tersebut, sehingga aturan ini melahirkan suatu pilihan kepada si mewaris apakah hendak menerima suatu warisan ataukah menolak suatu warisan atau bahkan menerima sebagian warisan yang dirasa menguntungkan bagi ahli waris (Moechtar, 2017).

Lembaga penolakan waris sendiri hanya dikenal dalam sistem Hukum Waris Perdata Barat saja, belum atau bahkan tidak dikenal kelembagaan tersebut baik di dalam sistem pewarisan di dalam 


\section{Kajian komparatif lembaga penolakan waris dalam perspektif hukum waris adat dan Islam}

Oemar Moechtar, Baren Valentino, Denita Cahyanti Wahono

Hukum Waris Adat maupun di dalam Hukum Waris Islam. Hal ini dapat dilihat secara nyata, bilamana ada seseorang yang beragama Islam meninggal dunia, maka ahli warisnya akan mengumumkan kepada para pelayat yang hadir agar bilamana si pewaris dalam hal ini seseorang yang meninggal dunia memiliki utang, hendaknya menyampaikan kepada ahli waris, hal ini dipercaya oleh masyarakat sekitar bermaksud agar jalan si pewaris menjadi lapang menuju akhirat. Contoh tersebut menjadi gambaran bahwa di masyarakat, tentunya yang beragama Islam belum bahkan tidak mengenal adanya lembaga penolakan waris, lebihlebih lagi bahwa dengan adanya kebiasaan tersebut tercermin bahwa Hukum Waris Islam mewajibkan adanya pembayaran suatu utang yang mana diwariskan kepada ahli warisnya. Padahal, menerima maupun menolak suatu waris merupakan hak seorang individu di mana terdapat kepentingan setiap ahli waris yang bersifat privat dan tertutup, sehingga seyogyanya tidak ada siapapun yang dapat mengatur seorang individu untuk menerima, memanfaatkan, maupun menolak suatu warisan.

Adanya macam-macam rezim hukum waris di Indonesia seperti ini akan menjadi problema di suatu hari sebab dapat disimulasikan bilamana seorang mewaris/ahli waris yang notabene tunduk pada Hukum Waris Adat atau Hukum Waris Islam dalam pewarisannya hendak melakukan penolakan terhadap suatu pewarisan namun yang terjadi tidak ada instrument hukum atau lembaga hukum yang dapat mengakomodir kehendak tersebut.

Problema selanjutnya yaitu mengenai apakah mungkin "meminjam" instrumen hukum dari BW untuk digunakan sebagai wadah lembaga hukum penolakan waris untuk yang tunduk kepada Hukum Waris Adat dan Hukum Waris Islam? Tentunya akan sukar dan tidak serta merta, mengingat sistem hukum waris di Indonesia yang memiliki kesinambungan terhadap aturan mengenai peng- golongan masyarakat di Hindia-Belanda pada masa Kolonial Belanda di dalam Pasal 131 Jo. 165 Indische Staatregeling (IS) walaupun aturan inipun sudah sangat tidak relevan mengingat saat ini telah berlaku Undang-Undang tentang Kewarganegaraan.

Sebelum Undang-Undang Kewarganegaraan berlaku, dikenal adanya suatu politik hukum yang diberlakukan oleh pemerintah kolonial HindiaBelanda sebagaimana diatur di dalam Indische Staatsregeling (IS) yang berlaku sejak 1 Januari 1926 yang merupakan pengganti atas Regerings Reglement Bentuk politik hukum kolonial yang dimaksud adalah adanya perbedaan kedudukan hukum yang menempatkan orang Eropa dalam kedudukan hukum yang lebih tinggi dari orang lainnya di Indonesia. Penggolongan itu sendiri terbagi menjadi 3 yaitu, golongan Eropa, golongan Bumi Putera dan golongan Timur Asing yang diatuir di dalam Pasal 131 IS.

Lebih lanjut di dalam Pasal 163 IS mengatur mengenai persyaratan atas siapa yang dapat masuk ke golongan yang mana dengan tujuan agar jelas keberlakuan hukum yang mana yang berlaku atas masing-masing mereka itu sebagai berikut (Jamali, 2011): 1. Golongan Eropa, yang tunduk adalah semua orang Belanda serta semua orang yang berasal dari Eropa dan Jepang dan semua orang dari tempat lain yang tunduk pada hukum keluarga yang sama dengan hukum Belanda; 2. Golongan Bumi Putera yang tunduk adalah orang-orang Bumi Putera kecuali bagi Kristen pribumi yang diatur dengan ordonansi; 3. Golongan Timur Asing, yang tunduk adalah orang-orang Timur Asing kecuali bagi yang menganut agama Kristen maka diatur dengan ordonansi.

Namun seiring berlakunya Undang-Undang Nomor 12 Tahun 2006 Tentang Kewarganegaraan, maka tentunya keberadaan ketentuan Pasal 131 Jo. 163 IS sudahlah tidak memiliki relevansi atas keberlakuannya, mengingat penggolongan masyarakat di Indonesia tidak lagi terbagi ke dalam 3 golongan lagi sebagaimana yang diatur di dalam IS, akan 
tetapi saat ini hanya dikenal 2 kategori, yakni Warga Negara Indonesia (WNI) dan Warga Negara Asing (WNA) yang tentunya seperti seutai benang merah, berkorelasi pula pada sistem pewarisan di Indonesia yang "seharusnya" tidak lagi terpaku pada penggolongan masyarakat akan tetapi merujuk pada suatu ketentuan hukum waris yang unifikatif, termasuk pula di dalamnya mengenai kelembagaan penolakan waris.

Hukum Waris Adat dan Hukum Waris Islam di Indonesia belumlah mengenal istilah kelembagaan penolakan warisan, akan tetapi seiring berkembangnya masyarakat di Indonesia yang tentunya diikuti pula dengan setiap problemaproblema yang ada, tentu ada kebutuhan bahkan urgensi akan kehadiran suatu instrument hukum yang dapat mengakomodasi suatu penolakan waris di dalam Hukum Waris Adat dan Hukum Waris Islam sehingga tidak terjadi suatu kekosongan hukum. Dari antinomi inilah penulis tergerak untuk melakukan penelitian sehingga kekosongan hukum dalam hal penolakan warisan di dalam Hukum Waris Adat dan Hukum Waris Islam dapat teratasi.

\section{Metode}

Penelitian ini merupakan penelitian hukum. Pendekatan yang digunakan dalam penelitian ini, yaitu statute approach (pendekatan perundangundangan), dan conceptual approach (pendekatan konseptual). Penggunaan statute approach diperlukan oleh sebab penelitian hukum ini menelaah peraturan perundang-undangan yang berkaitan dengan upaya hukum yang dapat dilakukan untuk mengatasi kekosongan hukum yakni ketiadaan lembaga penolakan waris dalam Hukum Waris Adat dan Islam dengan menggunakan Hukum Waris Perdata Barat yang tertuang dalam BW sebagai alat komparasi yang proporsional. Penelitian hukum ini juga menggunakan conceptual approach yang mana bertujuan untuk menelaah konsep-konsep hukum yang berada di dalam pasal-pasal yang terdapat di dalam aturanaturan hukum yang ditelaah terutama yang berkaitan dengan konsep "lembaga penolakan waris", sebab pasal-pasal yang terdapat di dalam peraturan perundang-undangan pada dasarnya merupakan suatu proposisi yang terdiri atas rangkaian konsep hukum(Hadjon and Djamati, 2011).

\section{Pembahasan}

\subsection{Eksistensi Lembaga Penolakan Waris di Indonesia}

Indonesia dikenal sebagai negara yang memiliki pluralismenya di dalam hukum pewarisan, di mana hukum waris di Indonesia berlaku 3 rezim hukum yakni Hukum Waris Perdata Barat/BW. Hukum Waris Adat, dan Hukum Waris Islam. Ketiga rezim hukum waris ini tetap eksis hingga saat ini mengingat keberlakuan Pasal II Aturan Peralihan UUD 1945 yang menyatakan bahwa: "Segala badan negara dan peraturan yang ada masing langsung berlaku, selama belum diadakan yang baru menurut Undang-Undang Dasar ini", yang berkorelasi pada ketiga rezim hukum waris tersebut menjadi bagian sistem hukum pewarisan nasional, walaupun kemudian lahir Undang-Undang No. 62 Tahun 1958 dan Keppres No. 240 tahun 1957 yang mengandung inti bahwa penggolongan masyarakat di Indonesia sebagaimana yang diatur di dalam IS tidak diberlakukan lagi (Supriyadi, 2015).

Namun hingga saat ini sisa-sisa nilai dari penggolongan masyarakat dahulu masih terasa di dalam eksistensi 3 rezim hukum waris di Indonesia. Ialah Hukum Waris Perdata Barat/BW yang eksistensinya dapat tertakar dengan sifatnya yang normatif atau telah dituangkan dalam suatu perundang-undangan sehingga memiliki daya ikat yang pasti di dalam masyarakat.

Saat ini lembaga penolakan waris hanya dikenal di dalam BW saja, di mana diatur di dalam 


\section{Kajian komparatif lembaga penolakan waris dalam perspektif hukum waris adat dan Islam \\ Oemar Moechtar, Baren Valentino, Denita Cahyanti Wahono}

Pasal 1057 sampai dengan 1065 BW. Penolakan waris sendiri merupakan suatu tindakan bebas yang dapat dilakukan oleh seorang ahli waris, mengacu pada Padal 1045 BW yang berisikan: "Tiada seorang pun diwajibkan untuk menerima warisan yang jatuh ke tangannya". Secara gramatikal suatu waris di dalam perspektif Hukum Waris Barat BW memberikan peluang kepada para ahli waris untuk menentukan, apakah ia akan menerima suatu warisan, menerima dengan suatu catatan (sebagian), ataukah menolak suatu warisan. Reasoning dari ketentuan ini terlihat jelas, bahwa pewarisan tidaklah dapat dimaknai hanya sebagai peralihan harta benda kepada ahli waris semata atau penerusan harta benda dari leluhur kepada anak cucu guna dilestarikan dalam perspektif Hukum Waris Adat, namun harus disikapi bahwa ada hal yang lebih kompleks yakni beralihnya aktiva dan pasiva serta konsekuensi dari masing-masing hal tersebut.

Dahulu, apa yang diwariskan adalah berupa suatu obyek yang memiliki nilai baik ekonomis, historis, maupun filosofis sebagaimana terjadi pada masyarakat adat, seperti di dalam sistem pewarisan adat di dalam adat Minangkabau, di mana harta benda pusaka seperti rumah gadang yang notabene merupakan harta benda yang bersifat kolektif dan tidak dapat dibagi akan diteruskan oleh leluhur kepada para keturunannya untuk dimanfaatkan oleh para keturunannya dan dilestarikan agar tidak punah. Namun seiring perkembangan waktu, masyarakat mengenal adanya kegiatan perniagaan yang lebih modern, tidak lagi menggunakan satu moda berupa barter yang konvensional, akan tetapi dikenal pula alat transaksi lain berupa pembayaran dengan suatu alat bayar yang kini dikenal dengan uang, dan sistem lain yang menunjang kegiatan berniaga dengan menggunakan moda berupa utang atau penundaan kewajiban untuk membayar (kini disebut kredit).

Dalam perspektif Hukum Waris Barat inilah utang menjadi titik acu penting, sebab saat ini kegiatan perniagaan tidak lagi menggunakan cara tukar-menukar, akan tetapi memanfaatkan metode pembayaran bahkan menggunakan metode kredit yang akibatnya melahirkan pasiva bagi si berutang. Utang yang kemudian menjadi pasiva bagi penerima waris secara harfiah wajib untuk dibayarkan cepat atau lambat, namun bila seorang ahli waris menolak suatu warisan yang jatuh padanya, maka ia tidak berkewajiban untuk membayarkan utang tersebut dana akan dibayarkan menggunakan harta benda yang ia tolak tersebut melalui sebuah balai atau badan yang mengurus harta benda yang terbengkalai (saat ini disebut Balai Harta Peninggalan/BHP).

Hukum Waris Adat sendiri tidak dikenal adanya istilah lembaga penolakan waris, mengingat karakter dari Hukum Waris Adat adalah peralihan harta benda milik pewaris yang notabene adalah leluhur atau nenek moyang adat yang fungsi dari pewarisannya ialah guna pemanfaatan warisan guna kelangsungan hidup dan kelestarian masyarakat adatnya dan bukan untuk semata-mata dimiliki dan dimanfaatkan untuk kebutuhan pribadi saja (Supriyadi, 2015), sehingga tidak dikenal adanya suatu pasiva atau utang apalagi utang tersebut diwariskan atau dialihkan ke ahli waris.

Model mewaris yang dianut oleh masyarakat adat atau dalam hal ini perspektif Hukum Waris Adat begitu berbeda bila dibandingkan dengan Hukum Waris BW sebab secara historis, (Meta, 2014) Hukum Waris Adat perwujudan nilai-nilai yang hidup di masyarakat yang mana menjadi kebiasaan, di mana pada saat itu suatu perilaku usaha atau perniagaan tidaklah sekompleks saat ini, dengan nilai-nilai kekeluargaan dan gotong royong yang tinggi, bentuk-bentuk perniagaan tidaklah jauh daripada barter dan pinjam pakai yang dilakukan oleh masyarakat adat (Komari, 2011).

Kemudian lebih lanjut di dalam Hukum Waris Islam juga tidak dikenal istilah lembaga penolakan waris. Konsepsi pewarisan menurut 
Hukum Waris Islam (faraidh) ialah Ijbari yakni peralihan harta dari seorang pewaris kepada ahli warisnya berlaku dengan sendirinya menurut ketetapan Allah tanpa digantungkan kepada kehedak pewaris atau ahli warisnya, hal ini tertuang dalam Al-Quran tepatnya di dalam Surat Al-Nisa [4]: 13 yang bila diterjemahkan berisi: "(Hukum-hukum pembagian warisan yang disebutkan) itu adalah ketentuan-ketentuan dari Allah. Barangsiapa taat kepada Allah dan Rasul-Nya, niscaya Allah memasukkannya ke dalam surga yang mengalir di dalamnya sungaisungai, sedang mereka kekal di dalamnya; dan itulah kemenangan yang besar"(Suma, 2015). Karena sifatnya yang wajib (imperatif), maka pewarisan di dalam Hukum Waris Islam mewajibkan ahli waris untuk menerima warisan atau harta peninggalan pewaris sesuai dengan jumlah yang ditentukan dalam Al-Quran dengan telah mengurangi terlebih dahulu pengeluaran-pengeluaran guna kepentingan pewaris (Ilyas, 2011) (termasuk di dalamnya utang-utang dan pembayaran-pembayaran tertentu) sehingga yang diterima ahli waris adalah harta peninggalan yang telah bersih (Projodikoro, 1966).

Hukum yang tertulis di dalam Al-Quran, tidaklah dikenal suatu lembaga penolakan waris (Rahmita, 2017). Akan tetapi, menurut Neng Djubaidah, dalam artikelnya yang berjudul "Ahli Waris Dapat Menolak Pengalihan Paten" berpendapat bahwa dimungkinkan bagi seseorang yang tunduk pada Hukum Waris Islam untuk menolak suatu warisan atau "setidaknya" mengundurkan diri dalam menerima suatu warisan, dengan alasan bahwa pengalihan paten dapat dilakukan dengan cara diwariskan, dihibahkan, maupun dialihkan dengan sifat pengalihan yang transaksional (Djubaidah, 2010).

Beranjak dari sifat dan cara pengalihan paten inilah dapat diambil suatu benang simpul bahwa dimungkinkan adanya suatu penolakan atas suatu pengalihan paten karena suatu alasan tertentu, yang dialihkan melalui pewarisan maupun hibah.
Demikian pula pada ahli waris paten yang tunduk pada Hukum Waris Islam bila memandang bahwa paten yang akan ia terima tidak memiliki nilai dan daya manfaat bagi dirinya bahkan dapat mendatangkan suatu problem maka ahli waris penerima paten dapat melepaskan haknya untuk menerima pengalihan paten tersebut atau singkat kata menolak suatu warisan berupa paten. Dari kasus ini, menjadi suatu gambaran akan bukti pergeseran zaman di mana lembaga penolakan waris di dalam Hukum Waris Islam sangat diperlukan mengingat dimungkinkan seseorang yang tunduk pada Hukum Waris Islam untuk dapat menolak suatu warisan dengan suatu dasar yang dapat diterima oleh akal sehat seperti penolakan warisan terjadi karena adanya suatu kepentingan yang harus dilindungi oleh ahli waris penerima warisan.

\subsection{Peranan lembaga penolakan waris pada hukum waris adat dan Islam}

Pluralisme hukum waris di Indonesia tidak selalu berjalan dengan harmonis sehingga hal ini merupakan suatu konflik yang bernuansakan suatu kepentingan tertentu. Salah satu solusi yang dapat digunakan untuk menghadapi masalah tersebut adalah dengan melakukan suatu unifikasi hukum waris (Fauzi, 2016). Semangat unifikasi hukum waris diwujudkan dalam suatu kodifikasi hukum waris yang bersifat diferesiansi yang mana adanya kesatuan hukum yang bersifat umum dan berlaku bagi seluruh golongan namun ada pula hukumnya yang bersifat khusus untuk suatu golongan, hal ini dapat dilihat dalam UU Nomor 1 Tahun 1974 tentang Perkawinan (Nuzul, 2010).

Selain unifikasi hukum waris merupakan suatu amanat dari peraturan perundang-undangan, melalui TAP MPRS Nomor II Tahun 1960 dan dilanjutkan dalam Keputusan Badan Perencana Lembaga Pembinaan Hukum Nasional (BP-LPHN) Tahun 1962 (saat ini disebut dengan Badan Pembinaan Hukum Nasional/BPHN) yang mana 


\section{Kajian komparatif lembaga penolakan waris dalam perspektif hukum waris adat dan Islam}

Oemar Moechtar, Baren Valentino, Denita Cahyanti Wahono

mengatur bahwa asas hukum kekeluargaan di Indonesia hanya berlaku satu sistem kekeluargaan yakni, sistem parental, dengan menyesuaikan sistem-sistem dalam hukum adat ke dalam sistem parental serta hukum waris untuk seluruh rakyat diatur secara bilateral individual (Nuzul, 2010). Unifikasi hukum waris dapat terjadi dikarenakan perkembangan sosial masyarakat Indonesia akan berjalan menuju kekeluargaan dalam sistem parental sebagaimana dinyatakan oleh Muhammad, hal tersebut dapat diamati melalui 3 alasan yakni, alasan atas asas hukum adat, alasan atas asas hukum islam, dan alasan sosiologis (Muhammad, 2006).

Kemudian mengingat bahwa saat ini sudah tidak dikenal 3 golongan masyarakat di Indonesia sebagaimana yang pernah terjadi di masa pemerintahan Hindia-Belanda maka pembagian rezim hukum waris berdasarkan kesukuan dan golongan sudah tidak lagi relevan, mengacu pada Undang-Undang No. 62 Tahun 1958 dan Keppres No. 240 tahun 1957 yang mengandung inti bahwa penggolongan masyarakat di Indonesia sebagaimana yang diatur di dalam IS tidak lagi berlaku, dan sebagai gantinya saat ini berlaku UndangUndang Nomor 12 Tahun 2006 Tentang Kewarganegaraan Republik Indonesia di mana di dalam Undang-Undang ini tidak lagi dikenal penggolongan masyarakat akan tetapi hanya dikenal WNI dan WNA.

Hukum Waris Adat memiliki konsep tersendiri yang berbeda dengan Hukum Waris BW maupun Hukum Waris Islam, yakni sebagai suatu proses penerusan harta peninggalan dari generasi ke generasi berikutnya yang mana tidak harus memenuhi syarat kematian sehingga dalam pewarisan adat juga tercakup mengenai pengalihan harta benda orang yang masih hidup, dalam hal ini lembaga yang dimaksud adalah hibah(Supriyadi, 2015). Harta dalam Hukum Waris Adat sendiri terbagi menjadi harta yang tidak dapat dibagi dan harta yang dapat dibagi. Mengenai harta yang tidak dapat dibagi merupakan harta yang bersifat turun temurun dan kolektif sehingga tidak mungkin dimiliki oleh seseorang melainkan secara kolektif oleh klan atau bagian dari masyarakat adat yang diwariskan (Sihombing, 2017).

Harta yang dapat dibagi merupakan harta yang bersifat individual yang mana masing-masing ahli waris memiliki hak untuk itu. Pembagian harta warisan tersebut terkadang dilakukan ketika pewaris masih hidup dengan alasan bahwa harta kekayaan merupakan harta yang digunakan untuk kehidupan keturunannya sehingga orang tua melakukan pembagian ketika masih hidup guna memberikan bekal kepada anak yang memisahkan diri karena sudah dewasa atau menikah (Supriyadi, 2015).

Konsepsi atas pewarisan di dalam Hukum Waris Adat ini sangatlah berbeda dengan apa yang dikenal di dalam BW, di mana pewarisan hanya dapat terjadi oleh karena kematian bila merujuk pada Pasal 830 BW. Dalam Hukum Waris Adat sendiri ahli waris wajib menyelesaikan kewajiban dari pewaris atas seluruh utang-utangnya, hal ini demikian dikarenakan Hukum Waris Adat banyak terpengaruh dari Hukum Islam (Dien, 2014). Oleh karena karakter dari Hukum Waris Adat yang bersifat kolektif, berkesinambungan, tidak tertulis dan sifatnya yang teritorial sehingga tidak sama antara daerah yang satu dan yang lain maka dapat dipahami bahwa Hukum Waris Adat tidak mengenal adanya lembaga penolakan waris sebagaimana yang dikenal di dalam rezim Hukum Waris BW.

Berbeda halnya dengan Hukum Waris Adat, sikap ahli waris dalam Hukum Waris BW dapat dibagi menjadi 3 yaitu, menerima secara keseluruhan, menerima dengan syarat (beneficiary) dan menolak secara keseluruhan. Sikap ahli waris dalam hukum waris BW tersebut mencerminkan bahwa hukum waris BW kental sekali dalam sifat individual yang mana hubungan antara pewaris dan ahli waris tidak didasarkan pada asas keke- 


\section{Jurnal Cakrawala Hukum, Volume 11 No. 3 Desember 2020}

ISSN PRINT 2356-4962 ISSN ONLINE 2598-6538

luargaan melainkan pada asas kepentingan pribadi (Nugroho, 2016).

Hukum Waris Adat, hubungan antara pewaris dan ahli waris tidak didasarkan pada kepentingan pribadi melainkan ahli waris akan ikut bertanggung jawab atas utang-utang pewaris sekalipun dirinya tidak tahu menahu atas utang-utang tersebut. Namun tidak serta merta si ahli waris menggunakan seluruh kekayaannya demi melunasi utang-utang yang ditinggalkan si pewaris, alam pikiran Hukum Adat melihat bahwa pewaris yang pada waktu meninggalnya meninggalkan banyak utang yang tidak dapat dilunasi adalah merupakan suatu ketidakadilan sehingga perlunya perlindungan terhadap para ahli waris yang demikian itu selama tidak bertentangan dengan asas-asas hukum waris adat dan rasa keadilan (Nugroho, 2016).

Pewarisan di dalam Hukum Waris Islam, ada beberapa nilai yang memiliki kemiripan baik dengan rezim Hukum Waris BW maupun Hukum Waris Adat. Yang pertama dan utama ialah pewarisan di dalam Hukum Waris Islam adalah pewarisan yang bersifat $a b$ intestato, yang memiliki makna bahwa yang berhak mewarisi harta benda si pewaris adalah ialah seseorang yang memiliki hubungan darah maupun hubungan perkawinan dengan si pewaris, dan tentunya karena Hukum Islam menganut asas personalitas keislaman maka yang berhak menerima waris adalah seorang muslim juga.

Asas personalitas keislaman merupakan asas yang memberlakukan Hukum Islam terhadap orang yang beragama Islam (Mukallaf) (Rahmawati, 2018). Asas personalitas keislaman sendiri telah diatur dalam Pasal 1 angka 2 Undang-Undang Nomor 7 Tahun 1989 tentang Peradilan Agama yang menyatakan bahwa Peradilan Agama merupakan salah satu kekuasaan kehakiman untuk orang-orang beragama Islam. Asas ini juga terdapat dalam Hukum Perdata yakni Asas Personalitas yang menyatakan bahwa hukum diberlakukan mengikuti subjek hukumnya dan tidak terbatas pada keberadaannya. Suleman menyatakan terdapat empat dasar dalam asas personalitas keislaman, yaitu (Suleman, 2013): 1. Hukum yang diberlakukan adalah Hukum Islam, dalam hal ini adalah Kompilasi Hukum Islam; 2. Hukum yang diberlakukan berkaitan dengan keperdataan, keperdataan yang dimaksud merupakan keperdataan khusus yang meliputi persoalan perkawinan, kewarisan, wasiat, hibah, wakaf, dan sadakah; 3. Tempat penyelesaian hukum adalah Pengadilan Agama; 4. Yang berpekara beragama Islam.

Hal ini dipertegas dengan merujuk pada Pasal 171 huruf (c) Kompilasi Hukum Islam (KHI) yang menyatakan bahwa: "Ahli waris adalah orang yang pada saat meninggal dunia mempunyai hubungan darah atau hubungan perkawinan dengan pewaris, beragama Islam dan tidak terhalang karena hukum untuk menjadi ahli waris". Nilai ini memiliki kemiripan dengan apa yang diatur di dalam Hukum Waris BW, di mana pewarisan hanyalah terjadi oleh karena kematian, berbeda dengan Hukum Waris Adat yang dapat melakukan pewarisan pada saat si pewaris masih hidup. Terlihat dengan jelas perbedaan bahwa Hukum Waris BW dan Hukum Waris Islam memisahkan secara tegas pewarisan dan hibah, di mana Hukum Waris Adat tidak membedakan antara pewarisan dan hibah sebab pewarisan dapat dilakukan kapan saja.

Pewarisan menurut perspektif Hukum Waris Islam, konsepsi pewarisan ialah Ijbari yakni peralihan harta dari seorang pewaris kepada ahli warisnya berlaku dengan sendirinya menurut ketetapan Allah tanpa digantungkan kepada kehedak pewaris atau ahli warisnya, yang artinya bahwa sifat dari pewarisan dalam Hukum Waris Islam ialah rigid (imperatif), ahli waris diwajibkan untuk menerima warisan atau harta peninggalan pewaris sesuai dengan proporsinya dengan telah mengurangi terlebih dahulu pengeluaran-pengeluaran guna kepentingan pewaris. Akan tetapi, bila meru- 


\section{Kajian komparatif lembaga penolakan waris dalam perspektif hukum waris adat dan Islam}

Oemar Moechtar, Baren Valentino, Denita Cahyanti Wahono

juk pada pendapat ahli hukum Islam yakni AlMaraghi, menyatakan bahwa apabila suatu hukum dipandang telah tidak sesuai dengan kebutuhan, maka tindakan bijaksana yang perlu dilakukan adalah menghapus hukum tersebut dan menggantikannya dengan hukum lain yang sesuai dengan kebutuhan tersebut.

Hal tersebut kemudian didukung oleh pendapat Rasyid Ridla mengenai perubahan suatu hukum karena perbedaan waktu, tempat, dan situasi, yang berkonsekuensi dimungkinkannya diubahnya atau dibatalkannnya suatu hukum dengan hukum yang baru. Sebagai gambaran, Sayyid Qutbh, menyatakan bahwa surat AlBaqarah ayat 106 sebagai landasan naskh dalam AlQuran, diturunkan sebagai sanggahan atas tuduhan para yahudi terhadap ketidak konsistensiaan Nabi Muhammad SAW terkait pada perpindahan kiblat maupun perubahan petunjuk atau hukumhukum karena adanya pertumbuhan masyarakat dan kondisi mereka yang berkembang (Muchammad, 2015).

Kemudian bila mengacu pada suatu peristiwa hukum di Indonesia, terdapat Putusan Putusan Mahkamah Agung Nomor: 368 K/AG/1995 yang menyatakan bahwa ahli waris non-muslim dapat menerima bagian harta dari pewaris Muslim sebesar $1 / 9$ bagian dari harta, kemudian di dalam Putusan Nomor: K/AG/2010 dinyatakan bahwa ahli waris non-muslim tidak dinyatakan sebagai ahli waris namun mendapatkan bagian harta berdasarkan wasiat wajibah yaitu sebesar $1 / 4$ bagian, tentunya hal-hal ini merupakan suatu bentuk elaborasi hukum atas perkembangan hukum yang menyesuaikan perkembangan zaman yang semakin maju, mengingat bahwa kedua putusan ini telah mengesampingkan prinsip personalitas keislaman di dalam Hukum Islam (Ilyas, 2015).

Mengacu pada gambaran di atas, lembaga penolakan waris memang tidak dikenal di dalam rezim Hukum Waris Islam karena sifatnya yang ijbari atau imperatif, akan tetapi perlu disadari pula bahwa hukum juga berkembang mengikuti arah perkembangan zaman agar tetap dapat mengakomodir kebutuhan manusia sehingga dimungkinkan pula adanya suatu perkembangan hukum di dalam Hukum Waris Islam yakni dibentuknya suatu instrument berupa lembaga penolakan waris untuk mengakomodir kepentingan para ahli waris yang di suatu hari nanti dimungkinkan untuk melakukan penolakan atas suatu peralihan harta benda kepadanya (pewarisan) atas dasar satu dan lain hal, dan itu perlu dimaklumi mengingat bahwa menerima maupun menolak suatu warisan merupakan hak dari si ahli waris itu sendiri.

Hukum waris bersifat fakultatif, maka sangatlah relevan bila unifikasi di dalam sistem hukum waris terutama dalam konteks lembaga penolakan waris urgent untuk diaplikasikan. Permasalahanpermasalahan yang timbul dari kekosongan lembaga penolakan waris dalam system hukum waris Islam terlebih lagi dalam system hukum waris Adat tidak dapat dipungkiri meurpakan sesuatu yang berkelanjutan dan tidak memiliki titik temu dikarenakan dengan ketidakberadaan lembaga penolakan waris ini maka ahli waris tidak diberikan suatu hak pembelaan apapun untuk menyikapi warisan yang jatuh padanya. Terlebih lagi pengaturan system hukum waris yang fakultatif ini juga sudah tidak relevan dengan hukum nasional dikarenakan telah ada penggolongan penduduk berdasarkan Undang-Undang Kewarganegaraan yang membagi penduduk menjadi dua golongan yaitu WNI dan WNA.

\section{Simpulan}

Konsep pewarisan telah bergeser mengikuti arus zaman. Pewarisan tidaklah dapat dimaknai lagi sebagai sekedar suatu penerusan harta peninggalan leluhur kepada garis keturunan di bawahnya ataupun dinilai sebagai suatu kewajiban yang titah atau bersifat Ilahi lagi yang tidak memungkinkan penerimanya untuk melakukan suatu perbuatan 


\section{Jurnal Cakrawala Hukum, Volume 11 No. 3 Desember 2020}

ISSN PRINT 2356-4962 ISSN ONLINE 2598-6538

yang bertentangan dari sifat pewarisan itu sendiri akan tetapi dengan pergeseran zaman maka pewarisan perlu dipandang pula sebagai pengalihan suatu kepentingan baik kepentingan yang bersifat menguntungkan maupun merugikan bagi si penerima warisan (sepertinya halnya aktiva-pasiva).

Lembaga penolakan waris sangatlah penting terutama untuk melindungi kepentingan dari si penerima waris agar penerima waris dapat menimbang apakah menguntungkan atau malah merugikan penerima waris bila menerima suatu waris. Kemudian untuk menyikapi sifat dari sistem hukum waris di Indonesia yang fakultatif namun terdapat antinomi dalam kelembagaan penolakan waris maka sampai dengan adanya aplikasi unifikasi terhadap sistem hukum waris di Indonesia maka dapat digunakan alternatif sementara berupa menyitas norma hukum lembaga penolakan waris di dalam BW untuk digunakan pada pewarisan di Hukum Waris Adat dan Hukum Waris Islam guna menghadirkan suatu kepastian hukum dalam hal konteks penolakan waris di dalam hukum.

\section{Daftar pustaka}

Dien, M. S. 2014 Hak Waris Anak yang Lahir dari Hasil Inseminasi, Lex Privatum, 2(3), pp. 180-189.

Djubaidah 2010 Ahli Waris Dapat menolak Pengalihan Paten, https://www.hukumonline.com/berita/bacal lt4c335345648e3/ahli-waris-dapat-menolakpengalihan-paten/.

Fauzi, M. Y. 2016 Legislasi Hukum Kewarisan di Indonesia, Jurnal Pengembangan Masyarakat Islam, 9(2), pp. 53-76.

Hadjon, P. M. and Djamati, T. S. (2011) Argumentasi Hukum. Gadjah Mada University Press. Yogyakarta.

Haries, H. A. 2013 Pluralisme Hukum Kewarisan di Indonesia, Mazahib, 11(1), pp. 31-37.

Ilyas 2011 Tanggung Jawab Ahli Waris terhadap Hutang Pewaris Berdasarkan Hukum Islam, At-Tahdzib Jurnal Studi Islam Dan Muamalah, 13(3), pp. 125137.
Ilyas 2015 Kedudukan Ahli Waris Non-muslim Terhadap Harta Warisan Pewaris Islam Ditinjau Dari Hukum Islam Dan Kompilasi Hukum Islam, Kanun Jurnal Ilmu Hukum, 17(1), pp. 4-5.

Jamali, A. R. 2011 Pengantar Hukum Indonesia. Rajawali Press. Jakarta.

Komari 2011 Laporan Akhir Kompendium Bidang Hukum Waris. Jakarta: BPHN Departemen Hukum dan HAM.

Meta, K. 2014. Kedudukan waris anak angkat menurut hukum waris adat Bali. Jurnal Cakrawala Hukum, 19(1), 39-48.

Moechtar, 0. 2017 Kedudukan Negara sebagai Pengelola Warisan atas Harta Peninggalan Tak Terutur Menurut Sistem Waris Burgerlijk Wetboek, Yuridika, 32(2), pp. 282-309.

Muchammad, H. 2015 Waris Dan Wasiat Dalam Hukum Islam/: Studi Atas Pemikiran Hazairin Dan Munawir Sjadzali, Kanun Jurnal Ilmu Hukum, 3(1), pp. 11-12.

Muhammad, B. 2006 Susunan Hukum Kekeluargaan Indonesia Menuju ke Sistem Bilateral-Parental (Pandangan Sosiologis-Yuridis). Pradnya Paraminta. Jakarta.

Nugroho, S. S. 2016 Hukum Waris Adat Indonesia. Pustaka Iltizam. Solo.

Nuzul, A. 2010 Upaya Kodifikasi Hukum Kewarisan Secara Bilateral dengan Pola Diferensiasi dalam Masyarakat Pluralis, Mimbar Hukum, 22(3), pp. 465-481.

Projodikoro, W. 1966 Hukum Warisan di Indonesia. Sumur. Bandung.

Rahmita, N. M., \& Budiono, R. 2017. Analisis kompilasi hukum islam tentang tolok ukur hibah yang diperhitungkan sebagai warisan. Jurnal Cakrawala Hukum, 8(1), 75-85.

Rahmawati, E. 2018 Penerapan Asas Personalitas Keislaman di Pengadilan Agama Pontianak dalam Perkara Perkawinan bagi Pasangan yang Beralih Agama, Al'Adalah: Jurnal Hukum Islam, 10(2), pp. 157-172.

Sihombing, D. A. P. 2017 Pembagian Waris Adat Masyarakat Suku Bugis di Kecamatan Enok, Kabupaten Indragiri Hilir, Provinsi Riau, Premise Law Journal, 1(1), pp. 1-18. 


\section{Kajian komparatif lembaga penolakan waris dalam perspektif hukum waris adat dan Islam}

Oemar Moechtar, Baren Valentino, Denita Cahyanti Wahono

Suleman, H. Z. 2013 Asas Personalitas Keislaman dalam Kompilasi Hukum Islam (KHI), Al-Mizan, 9(1), pp. 181-192.

Suma, M. A. 2015 Menakar Keadilan Hukum Waris Islam Melalui Pendekatan Teks dan Konteks AlNushush, Ahkam: Jurnal Hukum Islam, 12(3), pp. 553-568.
Supriyadi 2015 Pilihan Hukum Kewarisan Dalam Masyarakat Pluralistik (Studi Komparisi Hukum Islam dan Hukum Perdata, Al'Adalah: Jurnal Hukum Islam, 12(3), pp. 553-568. 